\title{
IT Productivity Paradox pada Perguruan Tinggi Swasta
}

\author{
${ }^{1}$ Muhammad Harist Murdani, ${ }^{2}$ Mamik Usniyah Sari, ${ }^{3}$ Muharom \\ ${ }^{1,3}$ Universitas Wijaya Putra Surabaya \\ ${ }^{2}$ Institut Teknologi Sepuluh November \\ muhammadharist@uwp.ac.id ${ }^{1)}$ mamikusniyah@gmail.com ${ }^{2)}$ muharom@uwp.ac.id ${ }^{3)}$
}

\begin{abstract}
ABSTRAK.Pengambilan kebijakan terkait implementasi teknologi informasi pada perguruan tinggi harus disertai dengan komitmen yang didukung oleh analisa mengenai besarnya kontribusi teknologi informasi pada kinerja institusi. Sehingga implementasi tersebut tidak serta merta hanya mengikuti tren yang berlaku, dimana hampir semua perguruan tinggi yang lain telah melakukan implementasi teknologi informasi. Serta menghindari adanya investasi yang sia-sia dikarenakan adanya kesalahan kebijakan dalam implementasi teknologi informasi. Information Technology Productivity Paradox merupakan sebuah perspektif baru dalam bidang tatakelola teknologi informasi untuk mengetahui besarnya kontribusi teknologi informasi pada peningkatan kinerja. Implementasi teknologi informasi selalu melibatkan banyak pihak dan membutuhkan biaya yang cukup besar, sehingga selalu timbul sebuah pertanyaan dalam benak pengambil kebijakan, apakah biaya dan sumberdaya yang dialokasikan untuk implementasi teknologi informasi adalah sebuah investasi yang tepat atau sia-sia. Tujuan penelitian ini adalah mendapatkan sebuah model konseptual tentangvariabel yang berperan dalam pengaruh implementasi IT/Teknologi Informasi terhadap peningkatanproduktivitaspada perguruan tinggi dengan menggunakan pendekatan secara langsung dan tidak langsung. Diharapkan dengan adanya model ini, pimpinan perguruan tinggi mampu menghindari/meminimalisasi terjadinya kegagalan investasi Teknologi Informasi/ Paradox. Dari hasil penelitian, dapat disimpulkan bahwa sumberdaya TI memiliki pengaruh secara langsung yang lebih signifikan daripada pengaruh secara tidak langsung,
\end{abstract}

Kata Kunci: IT Productivity Paradox; Implementasi Teknologi Informasi; Perguruan Tinggi

ABSTRACT.Policy for Information Technology (IT) implementation on Higher Ed. Institution should be supported by an analysis about the impact of IT Implementation on Higher Ed. Institution Productivity. IT Implementation tends to be a trend for nowadays Institution, where almost all of them are doing IT Implementation without cares for the high cost and resources spent on it. Which result will be a failure in IT investment because of a rash policy and decision for IT Implementation made by institution board director.IT Productivity Paradox is a relatively new perspective in IT Governance which purpose is to identify the contribution of IT to productivity. The natures of IT Implementation are high cost and plenty of people involved in it, which raise a question for policymaker whether cost and resource allocated for IT Implementation, is a success or a failure investment. The purpose of this research is to develop a conceptual model that explain all variable which impacted IT Implementation on increasing Productivity of Higher Ed. Institution by using direct and indirect approaches. We hope by using this model, Institution board director will be able to avoid and minimized the failure of IT Implementation investment or prevent the happenings of IT Productivity Paradox.

Keywords: IT Productivity Paradox; IT Implementation; Higher Education Institution

\section{PENDAHULUAN}

Pengembangan sebuah Perguruan Tinggi merupakan suatu keharusan dalam menghadapi perdagangan bebas melalui Masyarakat Ekonomi Asean (MEA). Untuk penguatan Perguruan Tinggi Swasta menurut Direktorat Jenderal Kelembagaan IPTEK dan Dikti, harus memenuhi syarat minimum: 1) Legalitas Badan Usaha 2) Kepemilikan Prasarana dan Sarana 3) Kepemilikan Keuangan 4) Kurikulum 5) Sumber Daya Manusia. Untuk itu Perguruan Tinggi perlu memiliki kemampuan manajemen dan kapasitas perencanaan yang mencukupi dalam membuat berbagai keputusan dan standar kualitas yang diharapkan. Salah satu metode pengembangan Perguruan Tinggi adalah penerapan atau implementasi teknologi informasi untuk menunjang kegiatan operasional serta meningkatkan pelayanan perguruan tinggi terhadap mahasiswa.

Semakin tinggi tuntutan masyarakat dan semakin ketat persaingan pada saat MEA, Perguruan Tinggi diharapkan untuk selalu mengembangkan sumber daya manusianya, khususnya tenaga dosen serta sarana dan prasarana pendukung proses akademik universitas sebagai satu kesatuan dalam proses pengembangan kapasitas Perguruan Tinggi secara berkelanjutan. Sarana dan prasarana ini meliputi pelayanan operasional yang mulai bergeser dari mode manual menuju pelayanan berbasis sistem, segala sesuatu yang sebelumnya 
bersifat offline berubah menjadi online. Dengan adanya pergeseran ini, diharapkan mahasiswa dan orang tua dari mahasiswa mampu melakukan pengawasan secara langsung terhadap kegiatan akademik masing-masing tanpa perlu berkunjung ke kampus.

(Salmi, 2009) menjelaskan tentang karakteristik dan hubungan beberapa faktor utama yang menjelaskan tentang World Class University. Salah satunya adalah transfer teknologi, Gambar 1, yang diawali dengan implementasi Sistem Informasi / IT pada proses bisnis dari Perguruan Tinggi.

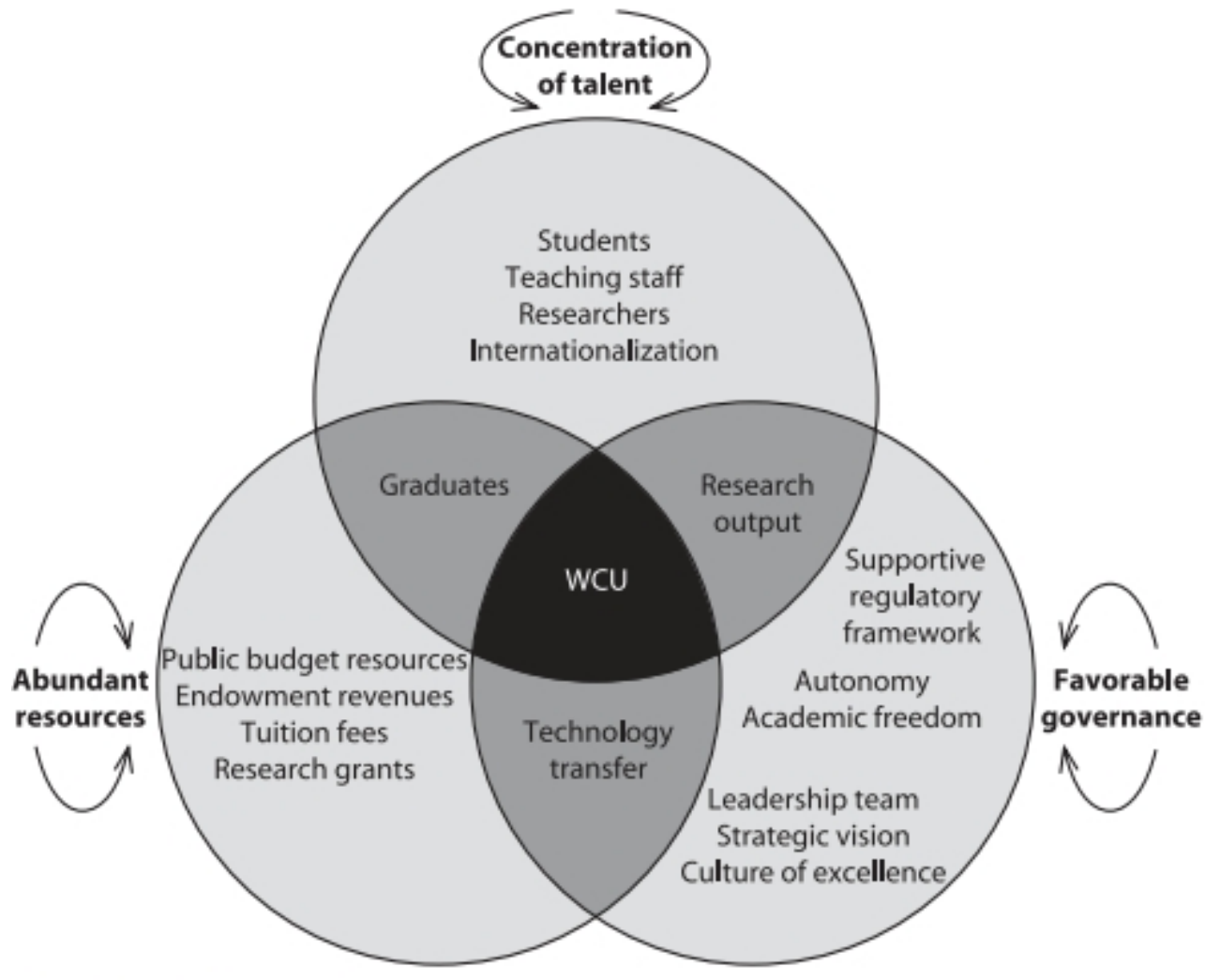

Source: Created by Jamil Salmi.

Gambar 1. Karakteristik World Class University

Prestise dari sebuah Perguruan Tinggi berasal dari banyaknya mahasiswa yang mendaftar dan seberapa maju pelayanan yang diberikan. Secara tidak langsung, implementasi Teknologi Informasi mampu meningkatkan prestise dari sebuah Perguruan Tinggi. Akan tetapi, implementasi Teknologi Informasi tidak selalu berhasil namun pasti membutuhkan biaya dan sumber daya yang cukup besar. Sehingga kebijakan implementasi teknologi informasi harus benar-benar dipikirkan secara matang. Tidak bisa hanya sekedar ikut-ikutan tren yang sedang berlaku saat ini. Kegagalan investasi implementasi teknologi informasi ditandai dengan minimnya peningkatan kinerja perguruan tinggi.Dengan kata lain, peningkatan kinerja perguruan tinggi tidak sesuai dengan besarnya biaya yang dikeluarkan. Permasalah an ini dapat disebut sebagai IT Productivity Paradox.(McGrath, 2013) menyebutkan bahwa kemampuan berinovasi merupakan salah satu aspek penting dalam meningkatkan performa dan kompetitif dari sebuah institusi.

Hasil akhir yang ingin diketahui adalah apakah peningkatan kinerja Perguruan Tinggi sesuai dengan besarnya biaya yang akan dikeluarkan. Sesuai atau tidak sesuai, maka bisa diketahui faktor-faktor apa saja yang harus dibenahi terlebih dahulu sebelum melakukan implementasi teknologi informasi. Hal ini menjadi penting untuk pimpinan Perguruan Tinggi dalam menentukan kapan mereka harus melakukan implementasi teknologi informasi.

Model Relasi TI dan peningkatan kinerja yang diadopsi pada penelitian ini pernah digunakan pada badan usaha yang bergerak di bidang industri dan perbankan. (Subriadi, Hadiwidjojo, Djumahir, \& Sarno, 2013)menggunakan model IT Productivity dengan studi kasus pada beberapa Bank Perkreditan Rakyat di sekitar Gerbang Kertasusila dengan menggunakan pendekatan langsung dan tidak langsung. Pendekatan langsung didasari oleh prinsip Cobb-Douglas Production Function sedangkan pendekatan tidak langsung 
didasari olehteori keselarasan teknologi informasi dan Resource-based View. Kami menambahkan pengaruh dari kebijakan pemerintah pada pembentukan model untuk IT Productivity.

Penelitian ini akan mengembangkan dan memvalidasi sebuah model untuk (1) mengetahui hubungan antara Teknologi Informasi dan peningkatan kinerja di Perguruan Tinggi dengan menggunakan pendekatan langsung dan tidak langsung. (2) Menjawab pertanyaan apakah kebijakan pemerintah (dalam hal ini DIKTI) mempengaruhi kinerja dari Perguruan Tinggi.

Berdasarkan uraian di atas, maka yang menjadi rumusan masalah pada penelitian ini adalah:1) Pengembangan model IT Productivity untuk menjelaskan hubungan antara Teknologi Informasi dan kinerja di Perguruan Tinggi. 2) Memberikan pembuktian mengenai pengaruh kebijakan pemerintah (DIKTI) pada kinerja Perguruan Tinggi yang diwakili dalam model IT Productivity.

Adapun batasan masalah dalam penelitian ini adalah: (1) Pendekatan yang digunakan untuk menjelaskan IT Productivity adalah pendekatan langsung dan tidak langsung. (2) Pengumpulan data untuk memvalidasi model dilakukan di Universitas Wijaya Putra Surabaya. (3) Metode pengumpulan data yang digunakan adalah dengan menggunakan kuesioner

\section{METODE PENELITIAN}

Pada penelitian ini, ada beberapa teori pendukung yang digunakan diantaranya sebagai berikut:

\subsection{IT Productivity Paradox}

IT Productivity Paradox dapat didefinisikan sebagai ketidakselarasan antara investasi penggunaan Teknologi Informasi dengan peningkatan kinerja. (Solow, 1987) menyebutkan bahwa "We see the computer age everywhere except in the productivity statistics". Semenjak itu, istilah IT Productivity Paradox mulai muncul sebagai topik penelitian yang baru. Dilanjutkan oleh (Brynjolfsson \& Lorin, 1998) yang semakin mempopulerkan istilah itu. Periode penelitian IT Productivity Paradox terbagi dalam dua periode.

Pada periode pertama (1980 - 1994), sebagian besar peneliti menyatakan bahwa tidak ada keterkaitan antara investasi Teknologi Informasi dengan kinerja. (Roach, 1987)membandingkan kinerja dari pekerja Teknologi Informasi dan pekerja pabrik. Hasil yang didapatkan cukup mengejutkan, selama tahun 1970-1980 kinerja pekerja pabrik mengalami peningkatan sebesar $16.9 \%$. Sedangkan kinerja pekerja Teknologi Informasi yang didukung dengan investasi besar-besaran hanya meningkat sebesar 6.9\%. Disimpulkan bahwa Teknologi Informasi menimbulkan efek negatif pada kinerja. Pada periode kedua (1995 - sekarang), (Brynjolfsson \& Lorin, 1998)mengeluarkan beberapa hipotesa yang dimungkinakan menjadi penyebab terjadinya IT Productivity Paradox, antara lain: (1) adanya kesalahan pada pengukuran masukan dan keluaran, (2) adanya kesalahan pada manajemen Teknologi Informasi, (3) pendistribusian manfaat dari Teknologi Informasi, (4) jeda pada pembelajaran, penyesuaian dan restrukturisasi teknologi informasi. Hasil yang didapatkan, kontribusi dari investasi Teknologi Informasi dan pekerja IT terhadap kinerja perusahaan adalah positif dan lebih besar daripada kontribusi dari investasi dan pekerja non-IT.

\subsection{Teorema Resource Based View}

(Hitt, Ireland, \& Hoskisson, 2015) dan (Rothaermel, 2017) mengungkapkan bahwa Teorema Resource Based View adalah sebuah model, sudut pandang, teori yang menyatakan bahwa sumberdaya dan kapabilitas sebuah institusi adalah kunci sukses dalam mencapai daya saing dan performa yang lebih daripada competitor lainnya. RBV merupakan salah satu teori fundamental untuk melakukan analisa atas daya saing dari sebuah institusi atau perusahaan. Dengan mengidentifikasi dan mengatur penggunaan sumberdaya secara efektif, sebuah pelaku bisnis dapat mengoptimalkan aktivitas produksi untuk menguasai pasar. Dengan kata lain, penggunaan sumberdaya secara maksimum adalah acuan yang digunakan untuk mengatur strategi demi mencapai performa yang diinginkan melalui 1) diversifikasi penggunaan sumberdaya, 2) diversifikasi penggunaan sumberdaya yang mengarah pada diversifikasi produk, 3) penentuan pasar untuk prioritas penggunaan sumberdaya, 4) kebijakan perusahaan untuk memaksimalkan penggunaan sumberdaya yang ada.

(Rothaermel, 2017) menyebutkan bahwa aset fisik merupakan salah satu sumberdaya yang bisa dirasakan manfaatnya. Salah satu contohnya adalah peralatan produksi/operasional yang dimiliki oleh institusi/perusahaan. Aset fisik pada sebuah perusahaan logistik meliputi trailer, truk boks, gudang, forklift, dll. Sedangkan (Grant \& Jordan, 2015) menuliskan bahwa ICT (Information and Communication Technology) merupakan salah satu sumberdaya atau aset non-fisik yang dimiliki oleh sebuah perusahaan atau institusi. ICT adalah sebuah teknologi berbasis computer (hardware dan software) dan metode komunikasi (suara, data, dan jaringan) yang digunakan untuk menyimpan, memproses dan mendiseminasikan informasi(Marakas \& O' Brien, 2013). Sumberdaya ICT terdiri dari tiga elemen, yakni (1) infrastruktur teknologi (meliputi komputer, software dan jaringan), (2) sumberdaya manusia (meliputi staff ICT dan 
kepala biro), dan (3) hubungan antara ICT dan bisnis. Kepemilikan ICT terintegrasi didefinisikan sebagai kepemilikan atas informasi dan metode komunikasi yang meliputi infrastruktur, hubungan ICT dan bisnis, serta sumberdaya manusia untuk mengoperasikan ICT tersebut (Sudrajat, Djojo, Adhikara, \& Kartikasari, 2017).

Berdasarkan penelitian sebelumnya, kami mendefinisikan sumberdaya IT sebagai 1) Sumber Daya Manusia, 2) Sumberdaya Infrastruktur TI, 3) Sumberdaya Finansial, 4) Sumberdaya Kualitas Kerjasama yang menghubungkan TI dengan bidang yang lain, dan 5) Sumberdaya Pendukung.

Dalam penelitian ini, kami menggunakan model konseptual dan hipotesa penelitian yang digunakan oleh (Subriadi, Hadiwidjojo, Djumahir, \& Sarno, 2013) dan menambahkan pengaruh kebijakan pemerintah didalamnya. Berdasarkan karakteristik WCU pada Gambar 1.1, dapat dilihat bahwa ada peran pemerintah dalam mewujudkan sebuah perguruan tinggi yang memiliki prestise mendunia.

Model konseptual ini dikembangkan dengan tujuan untuk menjelaskan kontradiksi yang terjadi antara TI dan kinerja. Secara umum, model konseptual ini membandingkan pengaruh dari pendekatan langsung dan tidak langsung sumberdaya TI terhadap kinerja.

Beberapa penelitian terdahulu memberikan kesimpulan yang berbeda mengenai pengaruh sumberdaya TI secara langsung terhadap peningkatan kinerja. (Rezaei, Rezaei, Zare, Akbarzadeh , \& Zare, 2014) dan (Ajami \& Chadegani, 2014)menyebutkan bahwa sumberdaya IT memiliki pengaruh secara langsung dan positif terhadap peningkatan kinerja.

Pemilihan sumberdaya yang termasuk dalam kategori sumberdaya TI merupakan salah satu aspek yang penting, dikarenakan kondisi dan ketersediaan sumberdaya pada tiap-tiap perguruan tinggi pasti berbeda, dalam penentuan apakah TI mempengaruhi peningkatan kinerja. Berdasarkan opini yang dibentuk dalam sudut pandang Resource-based view yang disadur dari(Sudrajat, Djojo, Adhikara, \& Kartikasari, 2017); (Marakas \& O' Brien, 2013); dan (Grant \& Jordan, 2015), maka sumberdaya TI yang didefinisikan pada penelitian ini adalah: (1) Sumberdaya Manusia $\left(\mathrm{X}_{1.1}\right)$, (2) Sumberdaya Infrastruktur TI $\left(\mathrm{X}_{1.2}\right),(3)$ Sumberdaya Finansial $\left(\mathrm{X}_{1.3}\right)$, dan (4) Sumberdaya Kualitas Vendor $\left(\mathrm{X}_{1.4}\right)$.

Kinerja universitas adalah tingkat pencapaian prestasi dari universitas tersebut. Prestasi disini merupakan bagian dari pencapaian semua civitas akademik yang ada di dalamnya. Terutama yang berhubungan dengan jumlah mahasiswa baru yang diterima per tahun dan jumlah publikasi hasil penelitian yang dilakukan oleh tenaga pengajar. Dalam penelitian ini, kami menggunakan 2 tolok ukur untuk kinerja, yakni (i) Market Based Performance $\left(Z_{1}\right)$ yang menjelaskan mengenai kemampuan dari universitas dalam berkompetisi di bidang pemasaran, dalam hal ini perekrutan mahasiswa baru dan (ii) Operating Performance $\left(Z_{2}\right)$, yang merupakan tujuan secara ekonomis berdasarkan visi dan misi dari universitas serta digunakan untuk menjelaskan pengukuran keuntungan (profit), produktivitas dan posisi relatif dengan universitas yang lainnya.

Untuk mengetahui apakah sumberdaya TI secara langsung mempengaruhi kinerja dan atau sebaliknya, maka kami mengusulkan hipotesa pertama sebagai berikut:

Hipotesa 1: Sumberdaya TI berpengaruh secara langsung terhadap peningkatan kinerja

Sumberdaya adalah bahan mentah yang digunakan untuk mengembangkan kemampuan sebuah perusahaan(Rothaermel, 2017). Kapabilitas TI sebuah perusahaan ditentukan oleh ketersediaan sumberdaya IT di dalamnya (Sudrajat, Djojo, Adhikara, \& Kartikasari, 2017)menjelaskan bahwa ada hubungan yang cukup erat antara sumberdaya dan kemampuan dinamis sangat bergantung pada penempatan dan penggunaan sumberdaya dengan sebaik-baiknya. Penempatan yang tepat ditambah dengan penggunaan sumberdaya yang efektif akan meningkatkan kompetensi dan kapabilitas dari sebuah perusahaan. Merujuk pada kondisi ini, maka hipotesa kedua kami adalah sebagai berikut:

Hipotesa 2: Sumberdaya TI mempengaruhi pada penempatan formasi karyawan yang memiliki kemampuan berbasis TI

Kapabilitas adalah sebuah proses kompleks yang secara efisien mengubah sumberdaya menjadi keluaran sebuah perusahaan (Hitt, Ireland, \& Hoskisson, 2015). Kapabilitas berbasis TI adalah kemampuan untuk melakukan mobilisasi, menterjemahkan, dan menggabungkan sumberdaya TI dengan sumberdaya nonTI yang lainnya. Secara umum, biasanya dilakukan oleh divisi TI untuk memberikan jasa layanan TI. Kapabilitas dapat dengan mudah diamati dengan menggunakan standar fungsional yang tergolong dalam aktivitas perusahaan (Rothaermel, 2017).

(Feeny \& Willcocks, 1998)menyebutkan bahwa aspek yang ada dalam kapabilitas TI adalah sebagai berikut: (i) aspek perencanaan dan pengembangan sistem $\left(\mathrm{Y}_{1.1}\right)$, (ii) aspek dukungan TI $\left(\mathrm{Y}_{1.2}\right)$, (iii) aspek penggunaan TI $\left(\mathrm{Y}_{1.3}\right)$. Ketiga aspek ini didasari oleh (i) cakupan kemampuan fungsional harus selaras dengan target dari perusahaan dan (ii) dari sudut pandang strategis, performa perusahaan jauh lebih penting daripada peningkatan kemampuan TI. Kesimpulannya, peningkatan kemampuan TI yang tidak disertai dengan 
peningkatan kinerja berarti kemampuan fungsional TI tidak bertujuan kepada peningkatan kinerja. Sehingga, kemampuan perusahaan untuk mendukung kapasitas kompetensi utama dengan menggunakan TI sangat tergantung kepada kemampuan fungsional dari TI tersebut.

Dengan semakin berkembangnya kapabilitas berbasis TI, maka standarisasi yang dilakukan oleh pemerintah(Kemenristekdikti, 2016), semakin lama semakin dijaga dengan baik. Dari tahun ke tahun, terjadi perubahan mekanisme dan data pada pelaporan aktivitas perguruan tinggi tiap semester ke PDDIKTI. Perubahan ini memiliki kaitan erat dengan penggunaan perangkat lunak, sebagai produk dari TI. Sehingga kami mengajukan hipotesa selanjutnya adalah sebagai berikut:

Hipotesa 3: Kapabilitas berbasis TI berpengaruh terhadap perubahan kebijakan pemerintah terkait pada pelaksanaan pendidikan di perguruan tinggi

Terdapat sedikit perbedaan pada definisi performa atau kinerja di perusahaan dan perguruan tinggi. Di perusahaan, terutama lini produksi barang jadi, peningkatan kinerja didefinisikan sebagai peningkatan pada kapasitas produksi atau jumlah penjualan produk. Khusus pada perguruan tinggi, peningkatan kinerja direpresentasikan oleh peningkatan kualitas. Di Indonesia, lembaga yang berhak mengeluarkan keputusan mengenai mutu dari sebuah perguruan tinggi adalah BAN-PT (Badan Akreditasi Nasional - Perguruan Tinggi). Istilah standar mutu ini adalah akreditasi.

Akreditasi merupakan upaya pemerintah dalam melakukan standarisasi dan penjaminan mutu atas alumni dari sebuah perguruan tinggi. Akreditasi ada dua, yakni Akreditasi Perguruan Tinggi yang dilakukan oleh BAN-PT, dan Akreditasi Program Studi yang dilakukan oleh LAM PT (Lembaga Akreditasi Mandiri Perguruan Tinggi).

Pada akreditasiberdasarkan peraturan BAN-PT tahun 2010(Menteri Pendidikan Nasional, 2010), ada 7 standar yang diperiksa, yakni: (1) Standar Isi (Visi, misi, tujuan dan sasaran, serta strategi pencapaiannya), (2) Standar Proses (Tata pamong, kepemimpinan, sistem pengelolaan dan penjaminan mutu), (3) Standar Kompetensi Lulusan (Mahasiswa dan Lulusan), (4) Standar Pendidik dan Tenaga Kependidikan (Sumber Daya), (5) Standar Kurikulum, pembelajaran, dan suasana akademik, (6) Standar Pembiayaan, sarana dan prasarana, serta sistem informasi, (7) Standar Penelitian, Pelayanan/Pengabdian kepada masyarakat dan kerjasama. Untuk akreditasi ini, nilai yang dikeluarkan ada pada kisaran 0-400 dengan skala huruf seperti yang ada pada gambar 2 .

\begin{tabular}{|c|c|}
\hline Akreditasi & Nilai \\
\hline A & $361-400$ \\
\hline B & $301-360$ \\
\hline C & $201-300$ \\
\hline NA & $<201$ \\
\hline
\end{tabular}

Gambar 2. Range nilai hasil akreditasi

Sehingga, untuk hipotesa selanjutnya kami mengusulkan sebagai berikut:

Hipotesa 4: Kebijakan pemerintah terkait dengan pelaksanaan pendidikan di perguruan tinggi sangat mempengaruhi pada peningkatan dukungan TI pada kompetensi utama perguruan tinggi

Seleksi teknologi yang digunakan oleh universitas adalah sebuah aktivitas yang cukup riskan bagi keputusan strategis. Adanya kesulitan untuk melakukan klarifikasi teknologi mana yang tepat digunakan untuk sebuah universitas yang memberikan pengaruh positif terhadap kompetensi utama. (Kim, 2016) memberikan sudut pandang bahwa sumberdaya TI mempengaruhi kinerja melalui kapabilitas TI dan kompetensi utama TI, yang meliputi kapabilitas operasional, kapabilitas manajemen TI, dan kekhususan kompetensi utama. Proses identifikasi kompetensi utama merupakan hal yang sangat berpengaruh untuk memaksimalkan dukungan yang bisa diberikan oleh TI. Berdasarkan standar akreditasi yang dikeluarkan oleh BAN-PT, bisa disimpulkan bahwa adanya Sistem Informasi, yang merupakan produk dari TI, dianggap mampu meningkatkan kualitas dari sebuah Perguruan Tinggi. Kualitas ini termasuk kualitas layanan kepada mahasiswa dan kualitas pelaksanan proses belajar mengajar yang bisa diindikasikan dengan (1) peningkatan atau minimal animo pendaftar yang sama/meningkat dari tahun sebelumnya dan (2) peningkatan hasil akreditasi. Sehingga untuk hipotesa terakhir, kami mengusulkan sebagai berikut:

Hipotesa 5: Dukungan IT terhadap kompetensi utama mempengaruhi peningkatan kinerja Perguruan Tinggi. 
Konseptual model kami mengadopsi model pada (Subriadi, Hadiwidjojo, Djumahir, \& Sarno, 2013) yang ditunjukkan pada gambar 3 .

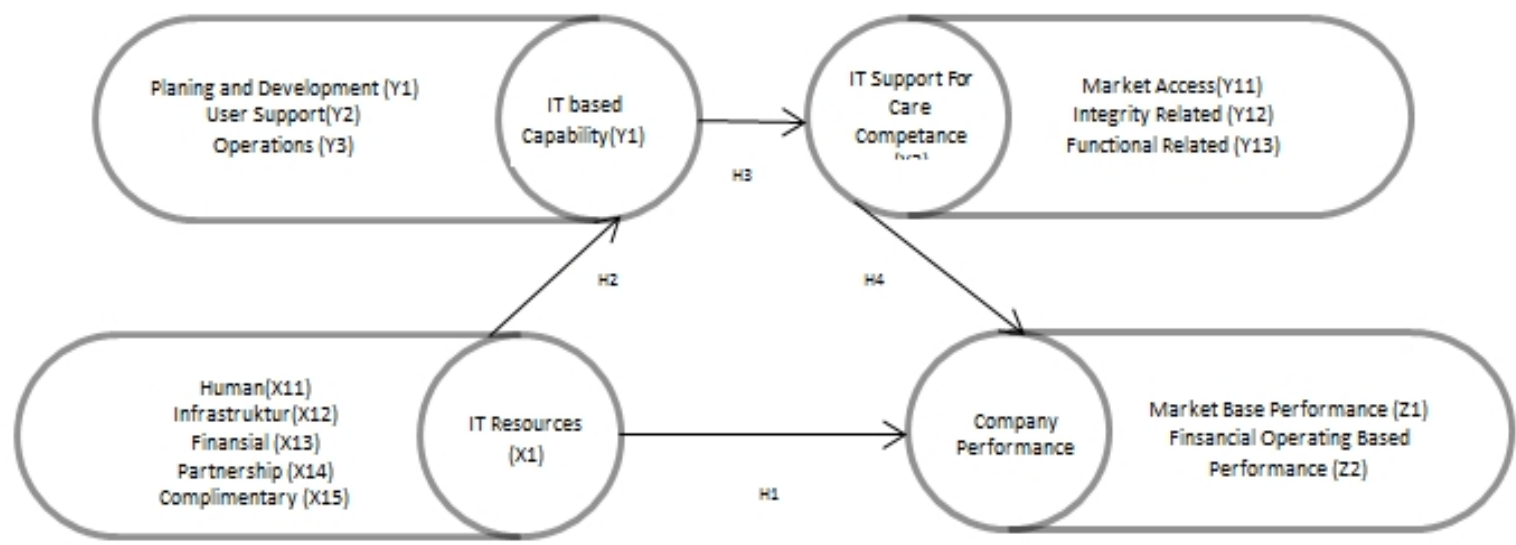

Gambar 3. Konseptual Model dari (Subriadi, Hadiwidjojo, Djumahir, \& Sarno, 2013)

Sedangkan konseptual model yang digunakan pada penelitian kali ini ada pada gambar 4.

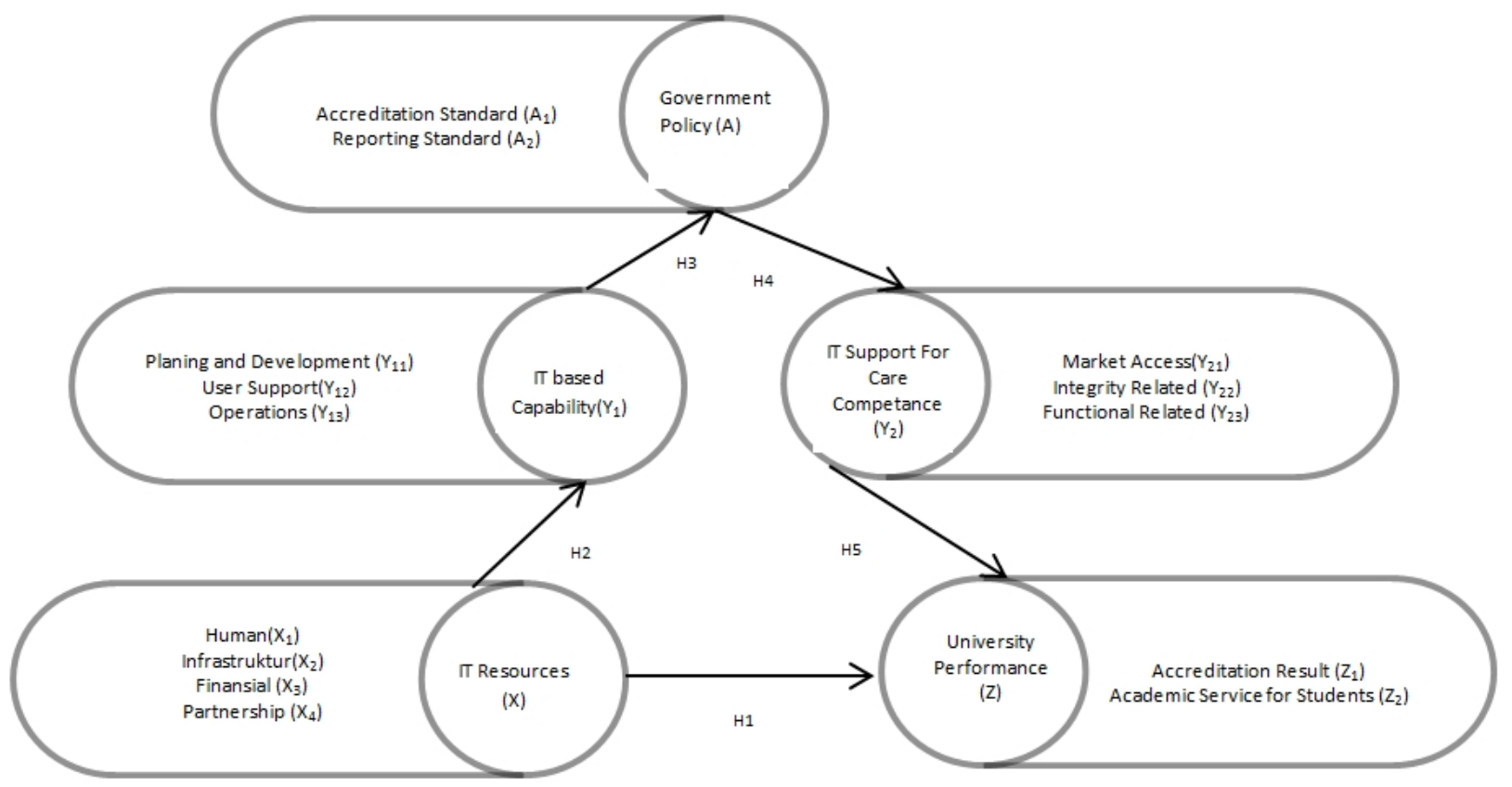

Gambar 4.Usulan Konseptual Model berdasarkan Hipotesa Penelitian

\subsection{Pengumpulan Data}

Dalam menyelesaikan penelitian ini, dilakukan pengambilan data dan kemudian dilanjutkan dengan validasi data. Data yang digunakan pada penelitian ini adalah data primer yang berasal dari penyebaran kuesioner dengan responden dari civitas akademik Universitas Wijaya Putra Surabaya, beralamat Jalan Raya Benowo No. 1-3 Surabaya. Data yang digunakan adalah data hasil kuesioner mengenai pengaruh penerapan Teknologi Informasi terhadap peningkatan kinerja perguruan tinggi. Pengisian kuesioner menggunakan skala $1-5$.

\subsection{Pengolahan Data}

Data Primer diperoleh dari 100 responden, yang terdiri dari 60 dosen/karyawan dan 40 mahasiswa lintas program studi. Untuk pengolahan data, digunakan metode GSCA (Generalized Structured Component 
Analysis)(Hwang \& Takane, 2004),karena metode ini mampu menganalisa konstruk dengan indikator yang bersifat reflektif dan formatif secara bersamaan serta mempu merepresentasikan pendekatan berbasis komponen untuk melakukan SEM (Structural Equation Modeling).

\section{HASIL DAN PEMBAHASAN}

Asumsi hubungan linier dari model perhitungan harus memenuhi syarat untuk analisa GSCA. Hasil testing linieritas dengan metode Curve Fit menunjukkan bahwa hubungan antar variabel latent memiliki signifikansi dibawah $5 \%(\mathrm{p}<0.05)$. Kesimpulan yang dapat diambil bahwa hubungan antar variabel latent dalam model struktural adalah linier.

Variabel performa univesitas memiliki dua indikator reflektif, yakni hasil akreditasi $\left(Z_{1}\right)$ dan pelayanan akademik $\left(Z_{2}\right)$. Loading estimate untuk masing-masing indikator adalah 0.960 dan 0.973 (Tabel 2), hasilnya adalah signifikan dan valid karena CR (Critical Ratio) $>1.96$. Sehingga kedua indikator ini memiliki validitas konvergen yang bagus untuk mewakili performa universitas.

Variabel sumberdaya TI (IT Resources) memiliki 4 indikator formatif, yakni sumberdaya manusia (Human Resources), infrastruktur TI, keuangan (finansial), dan dukungan vendor (partnership). Weight Estimate untuk sumberdaya $\mathrm{TI}\left(\mathrm{X}_{1}\right)$, infrastruktur $\mathrm{TI}\left(\mathrm{X}_{2}\right)$, finansial $\left(\mathrm{X}_{3}\right)$ dan dukungan vendor $\left(\mathrm{X}_{4}\right)$ adalah $0.063,0.085,0.049$, dan 0.978 . Indikator infrastruktur dan dukungan vendor adalah signifikan dan valid untuk CR $>$ 1.96. Sedangkan untuk indikator sumber daya manusia dan finansial menunjukkan CR yang tidak signifikan. Sehingga indikator yang dirasa cukup untuk mewakili variabel sumberdaya TI adalah infrastruktur dan dukungan vendor.

Terdapat 3 indikator formatif dalam variabel kapabilitas berbasis TI, yakni: perencanaan dan pengembangan (planning and support) $\left(\mathrm{Y}_{11}\right)$, Dukungan pengguna (User Support) $\left(\mathrm{Y}_{12}\right)$, dan penggunaan sehari-hari(operations) $\left(\mathrm{Y}_{13}\right)$. Berdasarkan hasil dari GSCA, didapatkan bahwa indikator dukungan pengguna dan penggunaan sehari-hari memiliki CR yang signifikan, yakni $>1.96$ dengan Weight Estimate masingmasing adalah 0.263 dan 0.969. Sedangkan indikator perencanaan dan pengembangan termasuk tidak signifikan.

Untuk kebijakan pemerintah, memiliki dua indikator formatif, yakni Standar Akreditasi $\left(\mathrm{A}_{1}\right)$ dan Standar Pelaporan $\left(\mathrm{A}_{2}\right)$. Standar Akreditasi menunjukkan hasil yang tidak signifikan, dengan Weight Estimate sebesar 0.084 dan CR 0.86. Sedangkan standar pelaporan menunjukkan hasil yang signifikan yang ditunjukkan dengan Weight Estimate sebesar 0.979 dan CR 30.62.

Variabel dukungan TI terhadap kompetensi utama memiliki 3 indikator formatif, yakni Market $\operatorname{Access}\left(\mathrm{Y}_{21}\right)$, Integrity Related $\left(\mathrm{Y}_{22}\right)$ dan Function Related $\left(\mathrm{Y}_{23}\right)$. Berdasarkan hasil uji, didapatkan bahwa Market Access memiliki hasil yang tidak signifikan, dengan Weight Estimate sebesar 0.008 dan CR 0.3. Sedangkan kedua indikator yang lain menunjukkan hasil yang signifikan dengan Weight Estimate sebesar 0.730 dan CR 8.0 untuk Integrity Related dan Weight Estimate sebesar 0.399 dan CR 3.56 untuk Function Related. Persepsi pada pengukuran indikator yang berhubungan dengan integritas menunjukkan bahwa TI pada universitas telah terintegrasi dengan baik pada bisnis proses dari universitas itu sendiri yang ditandai dengan kemudahan dalam mempersiapkan standar pelaporan ke kemenristekdikti menggunakan aplikasi FEEDER. Akses pasar kurang mewakili pada variabel dukungan TI dikarenakan pembangunan yang mulai merata. Ditandai dengan banyaknya universitas yang berbasis di luar pulau jawa, misal di pulau Sumatra, Kalimantan bahkan di daerah Sumbawa pun ada, yakni UTS (Universitas Teknologi Sumbawa).

Tabel 1. Korelasi antar variabel latent (SE)

\begin{tabular}{lccccc}
\hline \hline & Sumberdaya TI & Kapabilitas TI & $\begin{array}{c}\text { Kebijakan } \\
\text { Pemerintah }\end{array}$ & Dukungan TI & $\begin{array}{c}\text { Performa } \\
\text { Universitas }\end{array}$ \\
\hline $\begin{array}{l}\text { Sumberdaya } \\
\text { TI }\end{array}$ & 1 & $0.916(0.033)^{*}$ & $0.575(0.096)^{*}$ & $0.689(0.092)^{*}$ & $0.924(0.032)^{*}$ \\
$\begin{array}{l}\text { Kapabilitas } \\
\text { TI }\end{array}$ & $0.916(0.033)^{*}$ & 1 & $0.543(0.120)^{*}$ & $0.690(0.105)^{*}$ & $0.894(0.037)^{*}$ \\
$\begin{array}{l}\text { Kebijakan } \\
\text { Pemerintah }\end{array}$ & $0.575(0.096)^{*}$ & $0.543(0.120)^{*}$ & 1 & $0.835(0.036)^{*}$ & $0.577(0.096)^{*}$ \\
$\begin{array}{l}\text { Dukungan } \\
\text { TI }\end{array}$ & $0.689(0.092)^{*}$ & $0.690(0.105)^{*}$ & $0.835(0.036)^{*}$ & 1 & $0.690(0.096)^{*}$ \\
Performa & $0.924(0.032)^{*}$ & $0.894(0.037)^{*}$ & $0.577(0.096)^{*}$ & $0.690(0.096)^{*}$ & 1 \\
\hline \hline
\end{tabular}


Tabel 2. Loadings, AVE dan Alpha

\begin{tabular}{|c|c|c|c|c|c|c|}
\hline \multirow{2}{*}{$\begin{array}{l}\text { Konstruk/ } \\
\text { Variabel }\end{array}$} & \multirow{2}{*}{$\begin{array}{l}\text { Reflective } \\
\text { Indicators }\end{array}$} & \multicolumn{3}{|c|}{ Loading } & \multirow[t]{2}{*}{ AVE } & \multirow[t]{2}{*}{ Alpha } \\
\hline & & Est. & SE & $\mathrm{CR}$ & & \\
\hline \multirow{2}{*}{$\begin{array}{l}\text { University } \\
\text { Performance }\end{array}$} & Hasil Akreditasi & 0.960 & 0.018 & $54.11 *$ & \multirow[t]{2}{*}{0.934} & \multirow[t]{2}{*}{0.929} \\
\hline & $\begin{array}{l}\text { Pelayanan } \\
\text { Akademik }\end{array}$ & 0.973 & 0.014 & $69.47 *$ & & \\
\hline \multirow{2}{*}{$\begin{array}{l}\text { Konstruk/ } \\
\text { Variabel }\end{array}$} & \multirow{2}{*}{$\begin{array}{l}\text { Formative } \\
\text { Indicators }\end{array}$} & \multicolumn{3}{|c|}{ Weight } & \multirow[t]{2}{*}{ AVE } & \multirow[t]{2}{*}{ Alpha } \\
\hline & & Est. & $\mathrm{SE}$ & $\mathrm{CR}$ & & \\
\hline \multirow[t]{4}{*}{$\begin{array}{l}\text { Sumberdaya } \\
\text { TI }\end{array}$} & $\begin{array}{l}\text { Sumberdaya } \\
\text { Manusia }\end{array}$ & 0.063 & 0.053 & 1.2 & \multirow[t]{4}{*}{0} & \multirow[t]{4}{*}{0.240} \\
\hline & Infrastruktur & 0.085 & 0.038 & $2.25^{*}$ & & \\
\hline & $\begin{array}{l}\text { Sumberdaya } \\
\text { Finansial }\end{array}$ & 0.049 & 0.050 & 0.97 & & \\
\hline & $\begin{array}{l}\text { Relasi dengan } \\
\text { Vendor }\end{array}$ & 0.978 & 0.029 & $33.81^{*}$ & & \\
\hline \multirow[t]{3}{*}{$\begin{array}{l}\text { Kapabilitas } \\
\text { TI }\end{array}$} & $\begin{array}{l}\text { Perencanaan dan } \\
\text { Pengembangan }\end{array}$ & -0.131 & 0.108 & 1.21 & \multirow[t]{3}{*}{0} & \multirow[t]{3}{*}{0.439} \\
\hline & $\begin{array}{l}\text { Dukungan } \\
\text { Pengguna }\end{array}$ & 0.263 & 0.118 & $2.23^{*}$ & & \\
\hline & $\begin{array}{l}\text { Penggunaan } \\
\text { sehari-hari }\end{array}$ & 0.969 & 0.026 & $37.25 *$ & & \\
\hline \multirow[t]{2}{*}{$\begin{array}{l}\text { Kebijakan } \\
\text { Pemerintah }\end{array}$} & $\begin{array}{c}\text { Standar } \\
\text { Akreditasi }\end{array}$ & 0.084 & 0.097 & 0.86 & \multirow[t]{2}{*}{0} & \multirow[t]{2}{*}{0.349} \\
\hline & $\begin{array}{l}\text { Standar } \\
\text { Pelaporan }\end{array}$ & 0.979 & 0.032 & $30.62 *$ & & \\
\hline \multirow{3}{*}{$\begin{array}{l}\text { Dukungan TI } \\
\text { pada } \\
\text { kompetensi } \\
\text { utama }\end{array}$} & $\begin{array}{l}\text { Akses informasi } \\
\text { pemasaran }\end{array}$ & 0.008 & 0.026 & 0.3 & \multirow[t]{3}{*}{0} & \multirow[t]{3}{*}{0.752} \\
\hline & $\begin{array}{c}\text { Keterkaitan } \\
\text { dengan Integritas }\end{array}$ & 0.730 & 0.091 & $8.0^{*}$ & & \\
\hline & $\begin{array}{l}\text { Keterkaitan } \\
\text { dengan fungsi }\end{array}$ & 0.399 & 0.112 & $3.56^{*}$ & & \\
\hline
\end{tabular}

Tabel 3. Hasil testing hipotesa dan Path Coefficient

\begin{tabular}{|c|c|c|c|c|c|}
\hline Korelasi/Hubungan & Estimate & SE & $\mathrm{CR}$ & Empirical & Evidence \\
\hline Sumberdaya TI $\rightarrow$ Kapabilitas TI & 0.916 & 0.033 & $27.42 *$ & Signifikan & Diterima \\
\hline $\begin{array}{l}\text { Sumberdaya TI } \rightarrow \text { Performa } \\
\text { Universitas }\end{array}$ & 0.855 & 0.099 & $8.68 *$ & Signifikan & Diterima \\
\hline $\begin{array}{l}\text { Kapabilitas TI } \rightarrow \text { Regulasi } \\
\text { Pemerintah }\end{array}$ & 0.543 & 0.120 & $4.52 *$ & Signifikan & Diterima \\
\hline $\begin{array}{l}\text { Regulasi Pemerintah } \rightarrow \\
\text { Dukungan TI pada kompetensi } \\
\text { utama }\end{array}$ & 0.835 & 0.036 & $23.22 *$ & Signifikan & Diterima \\
\hline Dukungan TI pada kompetensi & 0.101 & 0.096 & 1.05 & Tidak signifikan & Tidak \\
\hline
\end{tabular}


Pengujian hipotesa dilakukan berdasarkan path coefficient dan Critical Value(CR). Dianggap signifikan jika $\alpha=0.05$ level atau CR $>1.96$. Berdasarkan tabel 3 dan gambar 3, dapat dilihat bahwa korelasi secara keseluruhan adalah signifikan kecuali korelasi antara dukungan TI terhadap kompetensi utama dengan performa universitas. Selain itu, semua korelasi antar variabel adalah signifikan. Dengan demikian, hipotesa $\mathrm{H} 1, \mathrm{H} 2, \mathrm{H} 3$, dan $\mathrm{H} 4$ dapat diterima sedangkan untuk hipotesa $\mathrm{H} 5$ tidak dapat diterima.

Sesuai dengan tujuan penelitian yakni membandingkan efek sumberdaya TI secara langsung dan tidak langsung pada peningkatan performa, hasil perbandingan ditunjukkan pada tabel 4 , dimana sebelah kiri menggunakan metode tidak langsung/ada variable mediasi dan sisi sebelah kanan merupakan metode langsung.

Tabel 4. Perbandingan hasil Path Coefficient

\begin{tabular}{|c|c|c|c|c|c|c|c|}
\hline \multicolumn{4}{|c|}{ Path Coefficient dengan variabel mediasi } & \multicolumn{4}{|c|}{ Path Coefficient tanpa variabel mediasi } \\
\hline & Estimate & SE & $\mathbf{C R}$ & & Estimate & SE & $\mathbf{C R}$ \\
\hline $\begin{array}{c}\text { Sumberdaya TI } \rightarrow \\
\text { Performa }\end{array}$ & 0.916 & 0.033 & $27.42 *$ & $\begin{array}{c}\text { Sumberdaya TI } \rightarrow \\
\text { Performa }\end{array}$ & 0.925 & 0.028 & $32.55 *$ \\
\hline $\begin{array}{c}\text { Sumberdaya TI } \rightarrow \\
\text { Kapabilitas TI }\end{array}$ & 0.855 & 0.099 & $8.68 *$ & - & & & \\
\hline $\begin{array}{c}\text { Kapabilitas TI } \rightarrow \\
\text { Kebijakan } \\
\text { Pemerintah } \\
\text { Kebijakan }\end{array}$ & 0.543 & 0.120 & $4.52 *$ & - & & & \\
\hline $\begin{array}{c}\text { Pemerintah } \rightarrow \\
\text { Dukungan TI }\end{array}$ & 0.835 & 0.036 & $23.22 *$ & - & & & \\
\hline $\begin{array}{c}\text { Dukungan TI } \rightarrow \\
\text { Performa }\end{array}$ & 0.101 & 0.096 & 1.05 & - & & & \\
\hline
\end{tabular}

\section{KESIMPULAN DAN SARAN}

Berdasarkan hasil perbandingan pada tabel 4, dapat disimpulkan bahwa sumberdaya TI memiliki pengaruh langsung yang lebih besar daripada pengaruh tidak langsung. Model penelitian beserta hipotesa yang diusulkan mampu menunjukkan pengaruh sumberdaya TI secara tidak langsung terhadap performa perguruan tinggi selangkah demi selangkah sesuai variabel laten yang tersedia. Model tersebut juga mampu menjelaskan fenomena IT Productivity Paradox yang mungkin terjadi pada sebuah perguruan tinggi. Hipotesa 5 menunjukkan hasil yang tidak signifikan, sehingga dimungkinkan untuk penelitian selanjutnya menggunakan variabel kebijakan pemerintah sebagai variabel bebas yang tidak tergantung pada kapabilitas TI.

\section{KETERBATASAN PENELITIAN}

Populasi atau sampel dari penelitian ini diambildi Universitas Wijaya Putra Surabaya saja, tanpa memperhatikan populasi yang lebih luas, misalnya universitas/perguruan tinggi swasta yang berada di bawah naungan kopertis VII. Populasi yang dipilih pun tidak memperhatikan jumlah mahasiswa yang dimiliki dan ketergantungan terhadap TI terhadap Perguruan Tinggi Swasta. 


\section{DAFTAR RUJUKAN}

Ajami, S., \& Chadegani, R. (2014). The effects of applying information technology on job empowerment dimensions. Journal of Education and Health Promotion, 84.

BAN PT. (2017). Peraturan BAN PT No. 4 Tahun 2017 tentang Kebijakan Penyusunan Instrumen Akreditasi.

BPS. (2016, Mei 20). Jumlah Penduduk dan Laju Pertumbuhan Penduduk Menurut Kabupaten/Kota di Provinsi Jawa Timur, 2010, 2014, dan 2015. Retrieved from Badan Pusat Statistik Provinsi Jawa Timur: http://jatim.bps.go.id

Brynjolfsson, E., \& Lorin, M. (1998). Beyond the Productivity Paradox. Communication of the ACM (Association for Computing Machinery), 41.

Feeny, D., \& Willcocks, L. (1998). Core IS Capabilities for Exploiting Information Technology. Sloan Management Review, 9.

Grant, R., \& Jordan, J. (2015). Foundations of Strategy. John Wiley and Sons, Ltd.

Hitt, M., Ireland, R., \& Hoskisson, R. (2015). Strategic Management Concepts: Competitiveness and Globalization. USA: South Western - Cengage Learning.

Hwang, H., \& Takane, Y. (2004). Generalized Structure Component Analysis. Psychometrika, 69, 81-99.

Kemenristekdikti. (2016). Permenristekdikti No 61 Tahun 2016 tentang Pelaporan Data Perguruan Tinggi.

Kim, J. (2016). Technological diversification, core technology competence, and firm growth. Research Policy, 45, 113-124.

Marakas, G., \& O' Brien, J. (2013). Introduction to Information Systems. New York: McGraw Hill.

McGrath, R. (2013). The End of Competitive Advantage: How to Keep Your Strategy Moving As Fast As Your Business. Harvard Business Review.

Menteri Pendidikan Nasional. (2010). Peraturan Menteri Pendidikan Nasional No 6 Tahun 2010 tentang perubahan atas peraturan menteri pendidikan nasional nomor 28 tahun 2005 tentang Badan Akreditasi Nasional Perguruan Tinggi.

Rezaei, M., Rezaei, M., Zare, M., Akbarzadeh , H., \& Zare, F. (2014). The Effects of Information Technology (IT) on Employee Productivity in Shahr Bank (Case Study of Shiraz, Iran). Applied Mathematics in Engineering, Management and Technology, 1208-1214.

Roach, S. S. (1987, April). America's Technology Dilemma: A profile of the Information Economy. Morgan Stanley Economic Study.

Rothaermel, F. (2017). Strategic Management: Concept and Cases. New York: McGraw-Hill.

Salmi, J. (2009). The Challenge of Establishing World-Class Universities. Washington DC: The International Bank for Reconstruction and Development/The World Bank.

Solow, R. (1987, July 12). We'd better watch out. New York Times Book Review, p. 36.

Subriadi, A. P., Hadiwidjojo, D., Djumahir, R., \& Sarno, R. (2013). Information Technology Productivity Paradox: A Resource Based View and Information Technology Strategic Alignment Perspective for Measuring Information Technology Contribution on Performance. Journal of Theoretical and Applied Information Technology, 54(3), 541-552.

Sudrajat, D., Djojo, B., Adhikara, T., \& Kartikasari, D. (2017). The Effect of Ownership of Logistics Physical Asset and Integrated ICT to Innovative Capability and Its Impact on Firm Performance. International Conference on Information Management and Technology (pp. 272-277). Yogyakarta: IEEE. 